Sains Malaysiana 50(8)(2021): 2469-2478

http://doi.org/10.17576/jsm-2021-5008-27

\title{
Situational Analysis for COVID-19: Estimating Transmission Dynamics in Malaysia using an SIR-Type Model with Neural Network Approach
}

(Analisis Keadaan untuk COVID-19: Penganggaran Dinamik Penularan di Malaysia menggunakan Model Jenis SIR dengan Pendekatan Rangkaian Neuron)

\author{
Mohammad Subhi Jamiluddin, Mohd Hafiz Mohd*, Noor Atinah Ahmad \& Kamarul ImRan Musa
}

\section{ABSTRACT}

COVID-19 is a major health threat across the globe, which causes severe acute respiratory syndrome, and it is highly contagious with significant morbidity and mortality. In this paper, we examine the feasibility and implications of several phases of Movement Control Order (MCO) and some non-pharmaceutical intervention (NPI) strategies implemented by Malaysian government in the year 2020 using a mathematical model with SIR-neural network approaches. It is observed that this model is able to mimic the trend of infection trajectories of COVID-19 pandemic and, Malaysia had succeeded to flatten the infection curve at the end of the Conditional MCO (CMCO) period. However, the signs of 'flattening' with $R_{0}$ of less than one had been taken as a signal to ease up on some restrictions enforced before. Though the government has made compulsory the use of face masks in public places to control the spread of COVID-19, we observe a contrasting finding from our model with regards to the impacts of wearing mask policies in Malaysia on $R_{0}$ and the infection curve. Additionally, other events such as the Sabah State Election at the end of third quarter of 2020 has also imposed a dramatic COVID-19 burden on the society and the healthcare systems.

Keywords: Basic reproduction number; neural network; non-pharmaceutical intervention; SIR Model

\section{ABSTRAK}

COVID-19 adalah ancaman kesihatan utama di seluruh dunia dan penyakit ini boleh menyebabkan sindrom pernafasan akut yang teruk. Ia sangat mudah berjangkit dan telah mengakibatkan kadar kematian yang signifikan. Dalam makalah ini, kami mengkaji kebolehlaksanaan dan implikasi beberapa fasa Perintah Kawalan Pergerakan (PKP) dan strategi campur tangan bukan farmasi (NPI) yang dilaksanakan oleh kerajaan Malaysia pada tahun 2020 dengan menggunakan model matematik melalui pendekatan SIR-rangkaian neuron. Kami mendapati bahawa model ini dapat memimik trend trajektori jangkitan pandemik COVID-19 dan Malaysia telah berjaya melandaikan lengkung jangkitan di akhir tempoh PKP Bersyarat (PKPB). Namun, tanda 'landaian'ini dengan $R_{0}$ kurang daripada satu telah diambil sebagai isyarat untuk melonggarkan beberapa sekatan yang dijalankan sebelum ini. Walaupun kerajaan telah mewajibkan penggunaan topeng muka di tempat-tempat awam untuk mengawal penyebaran COVID-19, kami memerhatikan hasil yang kontras daripada model kami berkenaan dengan kesan penggunaan topeng muka di Malaysia terhadap nilai $R_{0}$ dan juga terhadap lengkung jangkitan. Selain itu, peristiwa lain seperti Pilihan Raya Negeri Sabah pada akhir suku ketiga 2020 juga telah menyebabkan bebanan COVID-19 terhadap masyarakat dan sistem kesihatan negara.

Kata kunci: Asas nombor pembiakan; campur tangan bukan farmasi; Model SIR; rangkaian neuron

\section{INTRODUCTION}

In December 2019, a new coronavirus called SARS-CoV-2 (or previously referred to as 2019-nCoV) and the disease associated with this virus, COVID-19 (or also known as coronavirus disease 2019) have emerged (WHO Novel
Coronavirus Report 2020). The COVID-19 pandemic is now a major health threat across the globe and as of $23 \mathrm{rd}$ January 2021, there have been 99,299,728 confirmed cases and 2,128,826 deaths (Worldometers 2020). For Malaysia, 180,455 confirmed cases have been recorded with 667 
deaths occurred as of 23rd January 2021 (Abdullah 2021). In general, as of 23rd January 2021, the coronavirus has spread rapidly throughout different continents, with around 219 countries and territories having reported the presence of COVID-19 infected cases (CNN 2021).

To curb the severity of COVID-19 pandemic in the year 2020, the Malaysian government had implemented four phases of Movement Control Order (MCO) from 18th March 2020 till 3rd May 2020, followed by fiveweek of Conditional MCO (CMCO) and subsequently Recovery MCO (RMCO) period till the end of 2020 (Musa et al. 2021). Additionally, the government also employed the Enhanced MCO (EMCO/TEMCO) by applying the intervention plans in severely affected localities with the aim to restrict movement of residents in a particular area where the outbreaks emerged; subsequently, this strategy helped to reduce the interactions between high-risk groups and the rest of populations (Musa et al. 2021). This targeted approach had assisted in quicker active case detection, screening, testing and isolation of infected communities (Musa et al. 2021; Tang 2020).

In this work, we performed a situation analysis for COVID-19 in Malaysia using an SIR epidemiological model (Kermack \& McKendrick 1927; Mohd \& Sulayman 2020; Tolles \& Luong 2020) incorporating a neural network approach (Magri \& Doan 2020). This investigation aims to provide an insight into the feasibility and implications of the non-pharmaceutical intervention (NPI) strategies implemented by Malaysia in the year of 2020. To do this, we look at a range of control measures taken by the government and assess the impacts of distinct control regime on the basic reproduction number, $R_{0}$ (i.e. an epidemiological metric used to depict the number of secondary cases one case would produce in a completely susceptible population (Mohd \& Sulayman 2020; Tolles \& Luong 2020)) and in turn the COVID-19 pandemic curve. As a case study, the transmission dynamics are investigated using daily confirmed cases in Malaysia, where some of the parameters of the SIR-type system like transmission rate, removed rate and $R_{0}$ are estimated based on the fitting of the modelling framework to daily COVID-19 data from 1st February 2020 till 15th November 2020. It is important to note at the outset that given this novel coronavirus is a newly emerging viral infection, much remains to be understood about its transmission dynamics in the context of Malaysia as a developing country with limited medical resources; this is in fact the main focus of this research work.
The article is organized as follows. After describing the modelling framework in the next section, we compare the predictions of our system with the number of active cases in Malaysia and demonstrate the agreement between the two observations. Then, we assess the impacts of distinct MCO and other NPI strategies on the transmission dynamics of COVID-19 in Malaysia. We also discuss some intriguing findings with respect to the time-varying basic reproduction number $\left(R_{0}\right)$ of viral infection and how this threshold quantity affects the COVID-19 pandemic curve. Finally, we conclude the progress of studies to date and provide some recommendations on effective preventive measures to curb the spread of this pandemic.

\section{Materials AND Methods}

To model the transmission dynamics of COVID-19 in Malaysia, we employ a simple epidemiological SIR model incorporating a neural network approach. First, we outline the SIR-type ordinary differential equations (ODE) system that has been used in this work (Kermack \& McKendrick 1927):

$$
\begin{aligned}
& \frac{d S}{d t}=-\frac{\beta I S}{N} \\
& \frac{d I}{d t}=\frac{\beta I S}{N}-\gamma I \\
& \frac{d \tilde{R}}{d t}=\gamma I
\end{aligned}
$$

where the population of $N$ individuals are divided into three compartments: $S(t)$ corresponds to susceptible population at time $t$, which can be infected (with transmission rate of $\beta) ; I(t)$ corresponds to the number of infectious individuals at time $t$ and $\tilde{R}(t)$ corresponds to the number of individuals at time $t$ in removal class where those who have recovered or dead (with recovery or removed rate of $\gamma$ ) are removed from the population. Thus, $N=S+I+\tilde{R}$ and this initial-value problem is also subjected to initial conditions, $S_{0}, I_{0}$ and $\tilde{R}_{0}$.

Another variation of the modelling framework that can be used to examine the transmission dynamics of COVID-19 is an SEIR system, which contains additional variable $E$ to model the 'Exposed' compartment (He et al. 2020; Salman et al. 2021). While the SEIR system has the strength of being epidemiologically more realistic (compared to the SIR-type model), this modelling framework has some drawbacks of having additional 
unknown components in the system: the incubation (or latent) period and the initial latent population (Roda et al. 2020). Moreover, from the perspective of this work, which focusses on Malaysia as a case study, it would be rather hard to obtain the actual data on the 'Exposed' compartment since there is too little information being released and shared by the government with regards to this matter (Salman et al. 2021). Alternatively, SIR modelling framework has been employed to make further projections on the COVID-19 outbreaks in different countries such as Italy, China and France and the predictions from this model have been observed to be in agreement with the actual COVID-19 cases (Fanelli et al. 2020). Due to these reasons, we have decided to employ the formulated SIR system in this work since this simple modelling framework can be used meaningfully to draw qualitative conclusions on the evolution of COVID-19 pandemic in Malaysia.

The two parameters of the model (1) i.e., $\beta$ and $\gamma$ are assumed to be positive. In general, the SIR model parameters depict the COVID-19 pandemic time scales information. For instance: $1 / \gamma$ is the average time to recover or being removed from infected group, $1 / \beta$ is the average time between one contact (with an infected) and another person.

The basic reproduction number, $R_{0}$, of the model (1) is given as follows:

$$
R_{0}=\frac{\beta}{\gamma}
$$

The quantity $R_{0}$ is an epidemiologic metric used to describe the contagiousness of diseases and the severity of infection dynamics (Mohd \& Sulayman 2020; Salman et al. 2021; van den Driessche 2017).

For the implementation of neural network techniques (Magri \& Doan 2020), so as to calculate each compartmental group dynamics and estimate the two (time-varying) parameters of the system, the model (1) can be re-written in vectorized form:

$$
\begin{gathered}
\bar{q}^{\prime}=\bar{F}(\bar{q} ; \bar{\alpha}), \\
\bar{q}=\bar{q}_{0} \text { at } t=0,
\end{gathered}
$$

where $\bar{F}$ consists of the terms from SIR equations (1) and

$$
\begin{gathered}
\bar{q}=[S, I, \tilde{R}]^{T}, \\
\bar{\alpha}=[\beta, \gamma]^{T},
\end{gathered}
$$

are the column vectors of the state variables and parameters, respectively. This formulation is then treated as a constrained optimization problem (Magri \& Doan 2020):

Calculate: $\bar{q}$ and $\bar{\alpha}$

by minimizing: $E_{d} \equiv \lambda_{1}\left\|I-I_{C}\right\|^{2}+\lambda_{2}\left\|\tilde{R}-\tilde{R}_{C}\right\|^{2}$

subject to: an SIR model (3).

The term $\|\cdot\|$ is a norm and $\lambda_{1}$ and $\lambda_{2}$ pre-defined normalization factors. The term $E_{d}$ is a measure of the error between the candidate solution $(I, \tilde{R})$ and the data of confirmed infected and confirmed removed $\left(I_{C}\right.$, $\tilde{R}_{C}$ ). This formulation is inspired by the previous work of Magri and Doan (2020) whereby they developed a neural network algorithm that solves this constrained optimization problem for SIRD model; for further detail, we refer interested readers to their paper. In general, this formulation is based on the combination of solving ODE system (through time integration) and feedforwarding neural network techniques to assimilate the data into the modelling framework to learn the parameters $(\bar{\alpha})$ and state variables $(\bar{q})$.

Numerical simulations are conducted for this modelling framework and the results are discussed in the next sections. We parameterized this system using daily COVID-19 cases released by the Ministry of Health $(\mathrm{MOH})$, Malaysia in the interval between 1st February and 15th November 2020 (Abdullah 2021; Dong et al. 2020). In all cases, we employed numerical simulation using Python.

\section{RESULTS AND DISCUSSION}

We analyzed a compartmental system of SIR-type incorporating a neural network framework and calculate the active cases trajectory in Figure 1, which is predicted by the model (orange curve); in comparison, we also plotted the corresponding actual active cases in Malaysia (blue curve). Overall, we can see that the SIRtype model analysis agrees with the number of active cases in Malaysia and this system is able to mimic the trend of infection trajectories of the COVID-19 in our country. To get a better understanding on the impacts of 
distinct movement control orders on the transmission dynamics of COVID-19 in Malaysia, we demonstrated the daily infection curve in Figure 2 under different phases of MCO, CMCO, and RCMO strategies. From our modelling analysis (red curve) as compared to the actual daily data (blue curve) reported by $\mathrm{MOH}$, it could be observed that the implementations of MCO Phase 1 till Phase 4 were able to flatten the first two waves of infection in Malaysia and slow down the spread of the pandemic. For a developing country like Malaysia, which faces the problems of limited medical resources (e.g. tests, drugs, and hospital beds), this is crucial to ensure that the peak number of people requiring medical care due to COVID-19 at a time is reduced, and the health care system does not exceed its capacity.

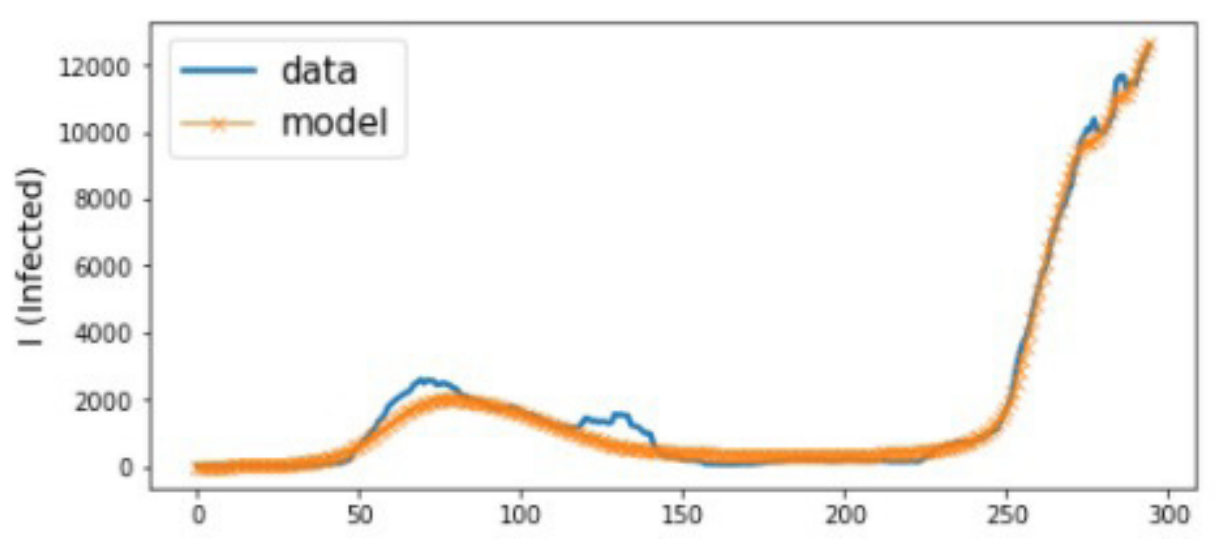

FIGURE 1. Infected curves of Malaysia using compartmental modelling frameworks till November 2020

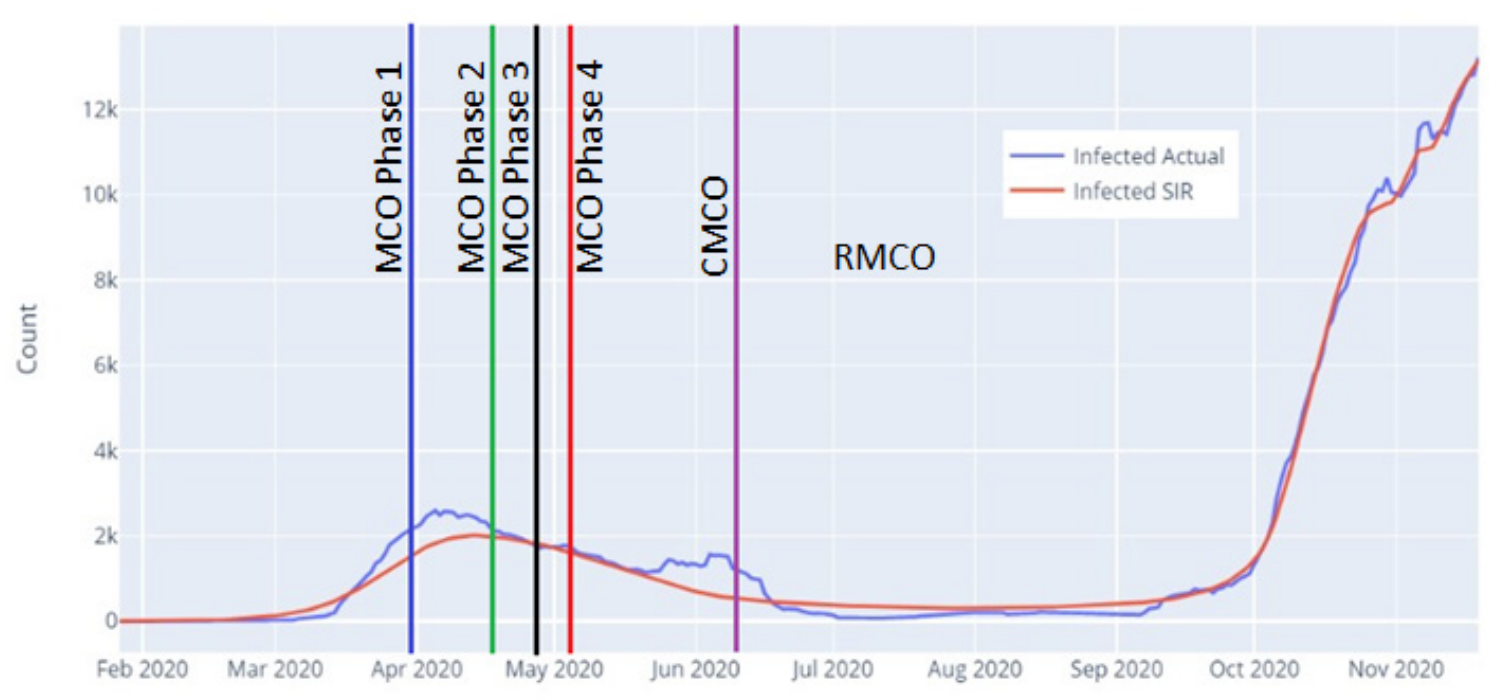

FIGURE 2. Infected curves of Malaysia using compartmental modelling frameworks till November 2020 
It could also be seen that after the end of MCO Phase 4, the infection curve exhibited another local maximum, which peaked around early of June 2020. This situation was due to the relaxations on the directives of $\mathrm{MCO}$, where some sectors could operate (e.g. construction and manufacturing industries) starting from MCO Phase 3; later, almost all job sectors could run at full capacity in MCO Phase 4 due to the economic needs; most of the businesses activities were allowed to run their operations as usual following standard operating procedures (SOPs) including physical distancing, temperature checks, and recording the names and contacts of customers. There were also some outbreaks of foreigner clusters in different detention centers in Malaysia (Bedi 2020a). Considering the need to balance out the control of COVID-19 spread and the economic demand, the Malaysian government had enforced the CMCO strategies till 9 June 2020. These intervention strategies, which included closure of schools and tertiary education institutions were able to further reduce the number of active cases in Malaysia and the infection curve had been kept to a low number of active cases during RMCO period till mid of July 2020.

To better understand the COVID-19 scenarios in Malaysia, we also examined the severity of this pandemic using basic reproduction number, i.e., $R_{0}$, given by (2). In Figure 3, we show that the estimated daily $R_{0}$ from 15 th March 2020 till 15th November 2020 calculated using our modelling framework.

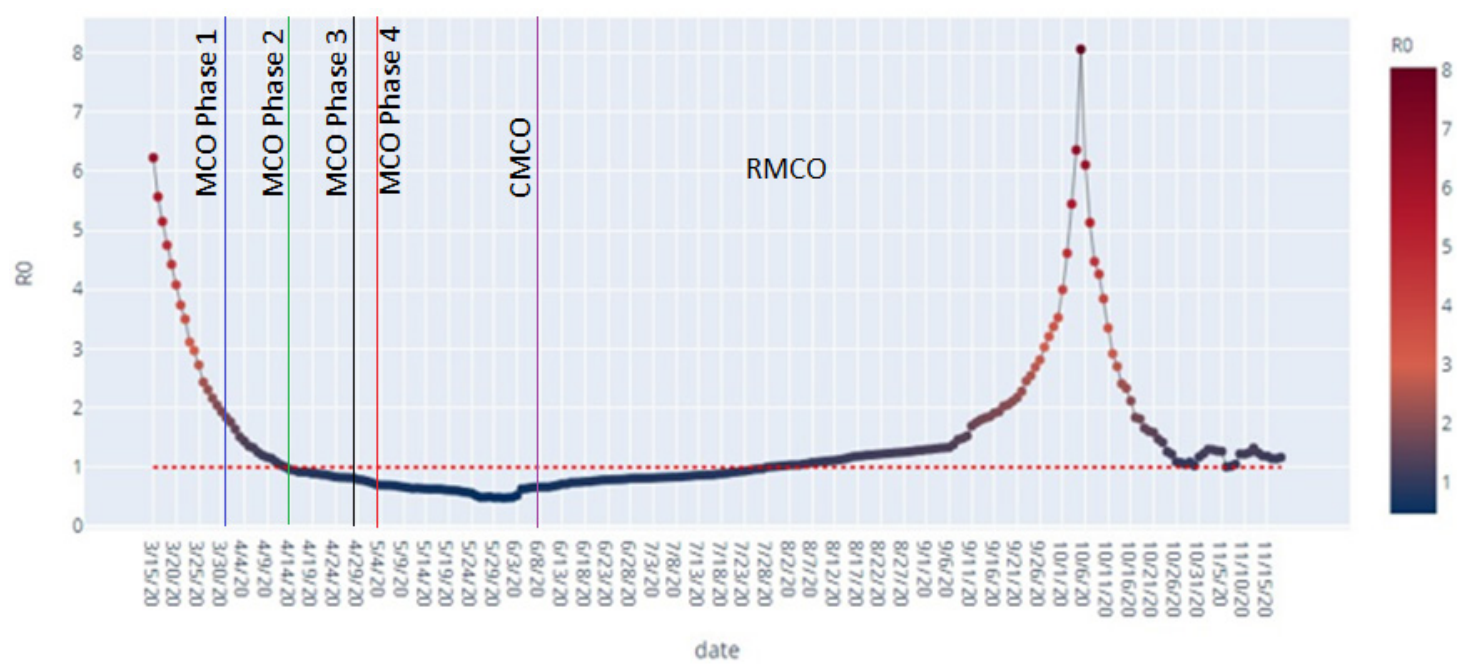

FIGURE 3. Time varying $R_{0}$ for Malaysia until 15 November 2020

Consistent with the observations from situational analysis discussed in Figures 1-2, we realized that the implementation of the first two phases of MCO had reduced $R_{0}$ for Malaysia significantly; but this quantity stayed above the value of one (dotted red line) till nearly the end of MCO Phase 2. Theoretically, $R_{0}$ of more than one means that the infection is spreading in the community, with more cases generated daily (Mohd \& Sulayman 2020; Tolles \& Luong 2020). This trend can be seen clearly from daily active cases during the first two waves of infection in Figure 2 whereby the infection curve peaked around 5th till 8th April 2020 with the highest 2596 active cases recorded on 5th April 2020 (Abdullah 2021; Mohd \& Sulayman 2020). The number of active cases 
also started to decrease during MCO Phase 3 till Phase 4; consequently, the modelling framework demonstrated that Malaysia had succeeded to push $R_{0}$ to be below the value of one till the end of CMCO period. In general, $R_{0}$ of less than one means that the chains of infection have been broken and disease transmission would inevitably die out in a long run (Mohd \& Sulayman 2020; Tolles \& Luong 2020), given that the intervention strategies are strictly enforced and adhered to.

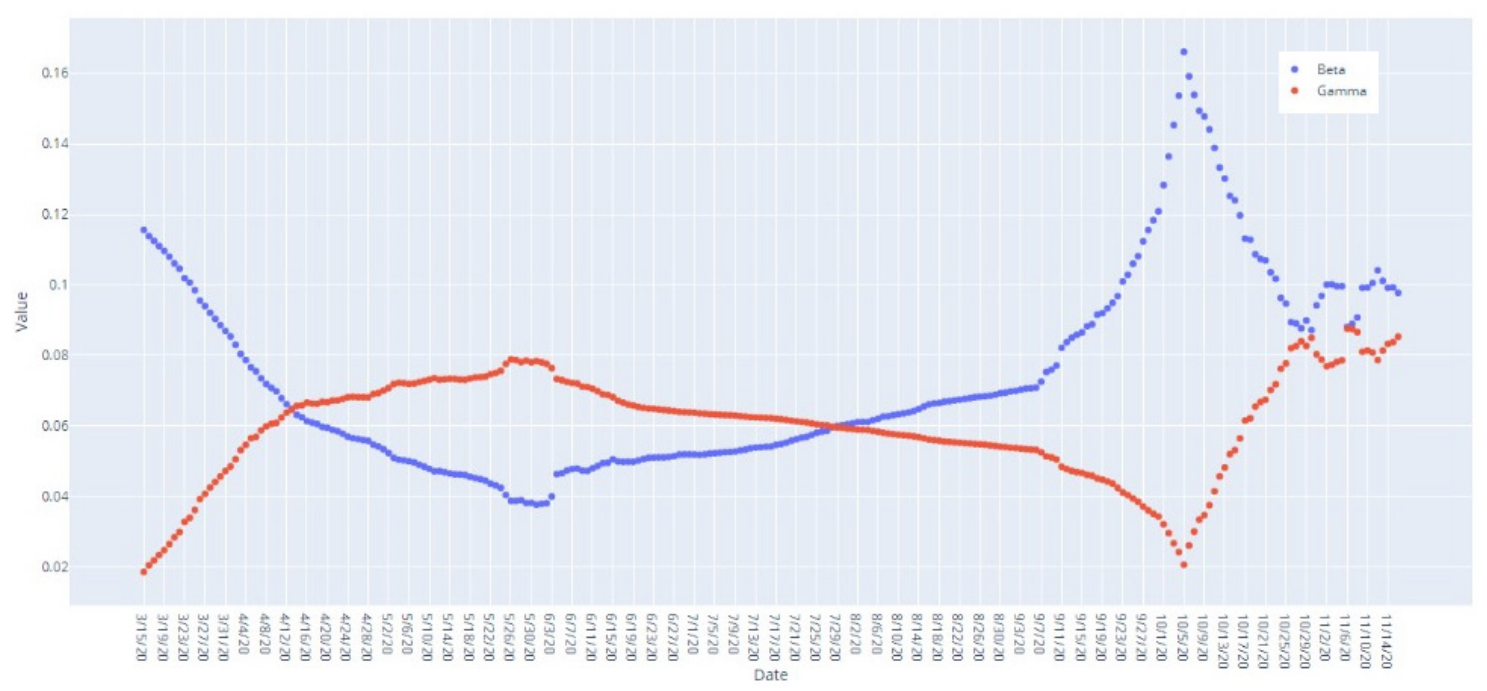

FIGURE 4. Estimated $\beta$ (transmission rate) and $\gamma$ (removed or recovery rate) parameters daily from 31st March 2020 till 15th November 2020

This observation is also evident even when we scrutinized the estimated parameters of the SIR model i.e., $\beta$ (transmission rate: blue dots) and $\gamma$ (removed or recovery rate: red dots) as shown by Figure 4 . The transmission rate started to reduce remarkably by the end of CMCO period and recovery rate also risen up, and this contributed to $R_{0}$ to be below than one. However, the signs of 'flattening' with $R_{0}$ of less than one that occurred during the $\mathrm{CMCO}$ and some portions of RMCO period had been taken as a signal to ease up on some restrictions enforced in Malaysia previously. As cases started to re-emerge following the easing of $\mathrm{MCO}-\mathrm{CMCO}$ strategies to the recovery phase, the Malaysian government has made compulsory the use of face masks in public places starting from 1st August 2020, after there was an increase in COVID-19 cases. By wearing face masks, medical experts suggest that it would help to reduce the probability of an infected person spreading coronavirus to others and may have been an important driver to control the spread of COVID-19 pandemic in different regions; these observations are in line with the findings of other modelling frameworks that predict substantial population-level impacts of widespread use of face masks (Howard 2021). Contrastingly, our results showed different observations with regards to the impacts of wearing mask policies as a standalone strategy in Malaysia on the basic reproduction number of viral infection and in turn the COVID-19 pandemic curve. As shown by Figure 3, we 
observe that the estimated values of $R_{0}$ started to rise above than one in early of August 2020 even though wearing a face mask in public places had been made compulsory by then. For instance, by 8 September 2020, the MOH projected the $R_{0}$ for Malaysia had risen to 1.72 (Ministry of Health Malaysia 2020a) and this infectivity rate agreed with our modelling result in Figure 3, which shown that $R_{0}$ was in the range of $1.65-1.75$ during this period. While wearing quality masks appropriately can reduce the basic reproduction number in a general population, our intriguing finding suggests that this NPI strategy may not be effective without combining this step with other strict prevention measures such as the shelter-in-place orders and full adherence to SOP e.g., social distancing.

There was another controversial event that occurred in Malaysia and significantly imposed the COVID-19 burden on the society and the healthcare systems (Rampal \& Liew 2021). Starting from the end of September 2020, Malaysia has seen an exponentially increasing trend of infection curve again (as in Figures 1-2) under the existing control regimes. This further increase in number of active cases had been attributed to the Sabah State Election, which took place on 26 September 2020 (Bedi 2020b; Rampal \& Liew 2021). The return of voters and politicians from Sabah to Peninsular Malaysia had caused a significant influx of COVID-19 cases nationwide (Rampal \& Liew 2021; Sukumaran 2020). Due to this reason, the daily reported cases increased dramatically with biggest daily jumps since the start of pandemic were recorded on 5th till 6th October 2020 (Abdullah 2021). This point can also be seen clearly from our daily estimated $R_{0}$ of Malaysia in Figure 3 where a dramatic spike in the infectivity rate occurred around similar time period (with the highest recorded $R_{0}$ of eight).

Similarly, in Figure 4, we can observe sudden shifts in the estimated parameter values of $\beta$ and $\gamma$. This situation may occur due to the change in government policies in handling COVID-19 cases: for instance, $\mathrm{MOH}$ had released an updated protocol for discharging confirmed COVID-19 case; while previously Malaysia had discharged both symptomatic and asymptomatic patients with COVID-19 after 14 days of quarantine and treatment period, on 5 October 2020 onwards, our country has employed the 10-day criteria (since symptom onset or their first positive RT-PCR test) to discharge these patients from infectious disease ward (Ministry of Health Malaysia 2020b). Inevitably, the recovered cases in Malaysia grow to four-digit figures and this may be one of the reasons behind the reduction in $R_{0}$ for Malaysia, as can be seen clearly from Figure 3 . Then, the estimated $R_{0}$ started to decrease and hover around the value of one from the end of October 2020 till 15th November 2020. This nonstationary evolution of $R_{0}$ maybe due to the weakening of control measures in Malaysia and reduced adherence to SOPs. It is also discovered that the estimated values of $R_{0}$ were around $1.1-1.24$ in November 2020 with some estimates of $R_{0}$, transmission rate $(\beta)$ and recovery rate $(\gamma)$ are shown in Table 1 . These estimates agreed with the basic reproduction numbers of Malaysia published by MOH in mid-November 2020, and they had found that $R_{0}$ lie in the range of 1.1 (Ministry of Health Malaysia 2020c). With regards to the discharge policy of confirmed COVID-19 case (Ministry of Health Malaysia 2020b) as discussed earlier, it is cautioned that this protocol should be implemented with care; theoretically, the average time to recover (or being removed from the infected group) is given by $1 / \gamma$ (Odagaki 2020); so, the lower the values of recovery rate $(\gamma)$, the longer the average time to recover for patients. For instance, based on Table 1 , the estimated value of $\gamma$ on 15th November 2020 is 0.08373; this would lead to the average time to recover of approximately 12 days, thus, the 10-day protocol used to discharge the COVID-19 patients should be used with prudence.

TABLE 1. Estimates of the basic reproduction number $\left(R_{0}\right)$. transmission rate $(\beta)$ and removed / recovery rate $(\gamma)$ for 13th - 15th November 2020

\begin{tabular}{rccc}
\hline Date & $R_{0}$ & $\beta$ & $\gamma$ \\
\hline 13th November 2020 & 1.24 & 0.10116 & 0.08136 \\
14th November 2020 & 1.19 & 0.09918 & 0.08326 \\
15th November 2020 & 1.18 & 0.09927 & 0.08373 \\
\hline
\end{tabular}


Infected Simulation

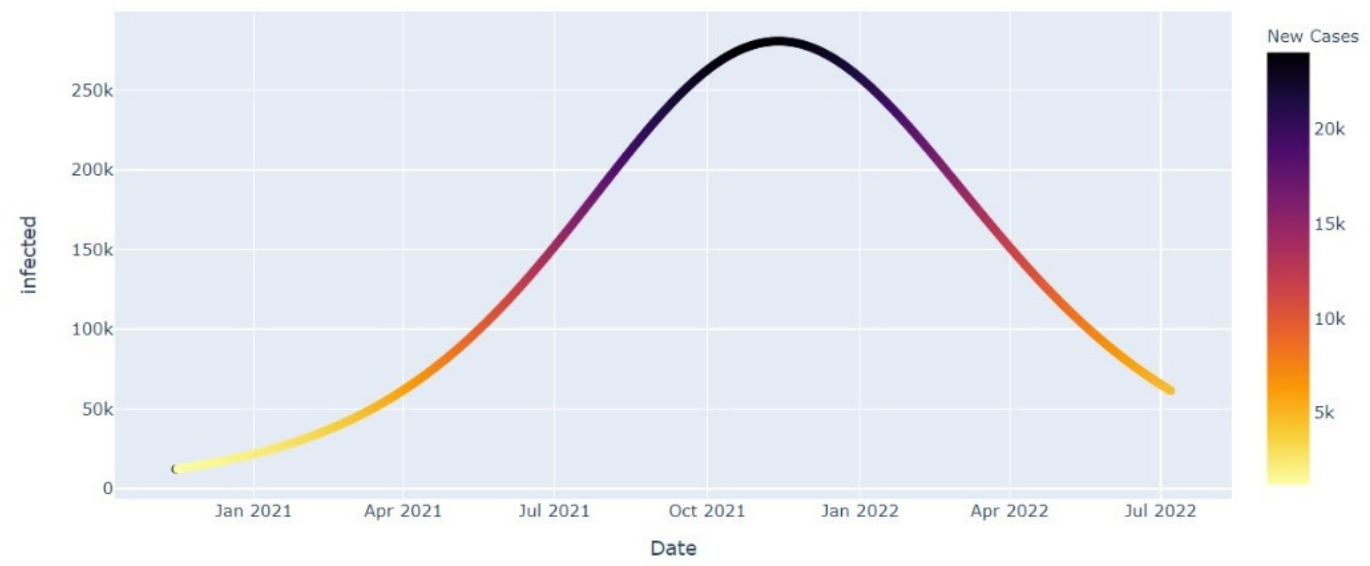

FIGURE 5. Long-term predictions of Malaysia COVID-19 worstcase scenario in the year of $2021-2022$

Using the corresponding estimates of transmission rate $(\beta)$ and removed rate $(\gamma)$ for Malaysia on 15 th November 2020 as shown in Table 1, we have also predicted the worst-case scenario of this pandemic in a long run as shown by Figure 5. This prediction was based on the following assumptions: the population of Malaysia at risk for COVID-19 is 32 million; the risk is homogenous for all residents in Malaysia; no strict intervention strategies employed to limit the transmission dynamics of COVID-19; no change in the levels of immunity. Based on Figure 5, the number of active cases is expected to increase dramatically, and the infected cases would continue to surge on an exponentially increasing trend. Without strict control measures nationwide like MCO and quarantine plus with the pharmaceutical intervention like the use of vaccines, it would be rather hard to reduce COVID-19 healthcare demand and mortality due to high numbers of infected populations. In the (unlikely) absence of strict control measures and spontaneous changes in individual behaviour (e.g. physical distancing), it is anticipated that a peak in active cases to occur approximately in the fourth quarter of 2021 . In such scenarios, given an estimated $R_{0}$ of 1.18 , it is predicted that over 270000 people in Malaysia would be infected over the course of the pandemic and this situation might overwhelm our health care infrastructures and medical resources; in such dire straits, the need for critical care bed capacity would be exceeded with an eventual peak in ICU demand would occur, which are often higher than what a developing country like Malaysia can supply.

\section{CONCLUSION}

As the COVID-19 pandemic progresses, Malaysia has tried its best to implement a variety of responses. Our analysis demonstrates that it would be necessary to combine several intervention strategies together in order to control the transmission dynamics of COVID-19. For instance, the policy of wearing face masks in public could help communities to slow the spread of COVID-19 when these masks are used along with other preventive measures, such as social distancing, frequent handwashing, and disinfecting. Our findings also suggest that populationwide social distancing like MCO, CMCO, and EMCO (or TEMCO) applied to the whole populations of Malaysia 
have the largest impact when being implemented with other control regimes like school, university, and workplace closure; these preventive measures may have the potential to suppress the transmission of COVID-19 and ensure that $R_{0}$ stays below than the value of one, which are necessary to rapidly reduce case incidence. By easing up on these social distancing strategies too soon (and too quickly), we caution that a rebound effect in transmission could occur and this possibility gives the novel coronavirus more opportunities to spread back in our communities. To avoid a rebound in transmission, which could cause serious spike in number of active cases and deaths, and waste all the progress that has been made so far, necessary preventive measures will need to be maintained until large stocks of vaccine are available to immunize the populations.

It is also hoped that the modelling insights we demonstrate through our results can highlight the importance to conduct more tests so that we will be able to detect the possibility of community transmission and asymptomatic cases in Malaysia. If we increase our testing capacity, then more possible cases will be picked up. The number of cases is likely to increase, however, the quality of data will be much better than what we have now, thus, allowing us to come up with a better prediction, for example in the analysis of reproduction number. Similar strategy had been employed by Singapore which led to high number of daily COVID-19 cases initially but helped the country to curb the spread of infection effectively. This crucial information from the community testing will help $\mathrm{MOH}$ and government to devise an early but effective contact tracing strategy, because all newly identified active cases detected could be placed on a 14-day quarantine - a process epidemiologists call as isolation - to contain the spread of this disease in the community further.

\section{ACKNOWLEDGEMENTS}

This research is conducted for COVID-19 Epidemiological Studies Special Team under the Ministry of Science, Technology, and Innovation (MOSTI), which is a part of the COVID-19 Epidemiological Analysis and Strategies (CEASe) Project (UM.0000245/HGA.GV). The first and second authors are also supported by Universiti Sains Malaysia (USM) Fundamental Research Grant Scheme (FRGS) No. 203/PMATHS/6711645.

\section{REFERENCES}

Abdullah, N.H. 2021. From the Desk of the Director-General of Health Malaysia (Kenyataan Akhbar KPK - Situasi Semasa Jangkitan Penyakit Coronavirus 2019 (COVID-19) di Malaysia). https://kpkesihatan.com/.

Bedi, R.S. 2020a. COVID-19 spike: 277 new cases; 270 from Bukit Jalil detention centre. The Star. https://www.thestar. com.my/news/nation/2020/06/04/covid-19-spike-277-newcases-no-deaths-for-13-straight-days.

Bedi, R.S. 2020b. Muhyiddin admits Sabah polls caused third COVID-19 wave. The Star. https://www.thestar.com.my/ news/nation/2020/11/18/muhyiddin-admits-sabah-pollscaused-third-covid-19-wave.

CNN. 2021. Tracking Coronavirus' Global Spread. https:// edition.cnn.com/interactive/2020/health/coronavirus-mapsand-cases/

Dong, E., Du, H. \& Gardner, L. 2020. An interactive web-based dashboard to track COVID-19 in real time. The Lancet Infectious Diseases 20(5): 533-534.

Fanelli, D. \& Piazza, F. 2020. Analysis and forecast of COVID-19 spreading in China, Italy and France. Chaos, Solitons \& Fractals 134: 109761.

He, S., Peng, Y. \& Sun, K. 2020. SEIR modelling of the COVID-19 and its dynamics. Nonlinear Dynamics 101(3): 1667-1680.

Howard, J., Huang, A., Li, Z., Tufekci, Z., Zdimal, V., van der Westhuizen, H.M., von Delft, A., Amy Price, A., Fridman, L., Tang, L-H., Tang, V., Watson, G.L., Bax, C.E., Shaikh, R., Questier, F., Hernandez, D., Chu, L.F., Ramirez, C.M., \& Rimoin, A.W. 2021. An evidence review of face masks against COVID-19. Proceedings of the National Academy of Sciences 118(4): e2014564118.

Kermack, W.O. \& McKendrick, A.G. 1927. A contribution to the mathematical theory of epidemics. Proceedings of the Royal Society of London Series A: 115(772): 700-721.

Ministry of Health Malaysia. 2020a. Press Statement MOH: Updates on the COVID-19 Situation in Malaysia. 8 September 2020 http://covid-19.moh.gov.my/terkini/092020/situasiterkini-08-september-2020/PS\%20DG,\%20COVID-19\%20 updates $\% 20(8 \% 20$ Sept $\% 202020)$.pdf.

Ministry of Health Malaysia. 2020b. Annex 2: Management of Suspected, Probable and Confirmed COVID-19 Case. http:// covid-19.moh.gov.my/garis-panduan/garis-panduan-kkm/ Annex_2_Management_of_Suspected,_Probable_and Confirmed_COVID_07102020.pdf

Ministry of Health Malaysia. 2020c. COVID-19 Unjuran R-Naught Malaysia 17 November 2020. http://covid-19.moh. gov.my/sorotan/112020/unjuran-r-naught-hari-ini-17112020.

Mohd, M.H. \& Sulayman, F. 2020. Unravelling the myths of R0 in controlling the dynamics of COVID-19 outbreak: A modelling perspective. Chaos, Solitons \& Fractals 138: 109943. 
Musa, K.I., Arifin, W.N., Mohd, M.H., Jamiluddin, M.S., Ahmad, N.A., Chen, X.W., Hanis, T.M. \& Bulgiba, A. 2021. Measuring time-varying effective reproduction numbers for COVID-19 and their relationship with Movement Control Order in Malaysia. International Journal of Environmental Research and Public Health 18(6): 3273.

Odagaki, T. 2020. Analysis of the outbreak of COVID-19 in Japan by SIQR model. Infectious Disease Modelling 5: 691-698.

Rampal, L. \& Liew, B.S. 2021. Malaysia's third COVID-19 wave-a paradigm shift required. The Medical Journal of Malaysia 76(1): 1-4.

Roda, W.C., Varughese, M.B., Han, D. \& Li, M.Y. 2020. Why is it difficult to accurately predict the COVID-19 epidemic? Infectious Disease Modelling 5: 271-281.

Salman, A.M., Ahmed, I., Mohd, M.H., Jamiluddin, M.S. \& Dheyab, M.A. 2021. Scenario analysis of COVID-19 transmission dynamics in Malaysia with the possibility of reinfection and limited medical resources scenarios. Computers in Biology and Medicine 133: 104372.

Sukumaran, T. 2020. Coronavirus Malaysia: PM blames Sabah election as among causes of huge infection surge. The South China Morning Post. https://www.scmp.com/week-asia/ health-environment/article/3104421/coronavirus-malaysiapm-blames-sabah-election-among.

Tang, K.H.D. 2020. Movement control as an effective measure against Covid-19 spread in Malaysia: An overview. Journal of Public Health: From Theory to Practice. https://doi. org/10.1007/s10389-020-01316-w.
Tolles, J. \& Luong, T. 2020. Modeling epidemics with compartmental models. JAMA 323(24): 2515-2516.

van den Driessche, P. 2017. Reproduction numbers of infectious disease models. Infectious Disease Modelling 2(3): 288-303.

WHO Coronavirus (2019-nCoV) Report. 2020. Novel Coronavirus (2019-nCoV) Situation Report. World Health Organization (WHO). https://www.who.int/docs/defaultsource/coronaviruse/situation-reports/20200121-sitrep-12019-ncov.pdf.

Worldometers. 2020. COVID-19 Coronavirus Pandemic Cases. https://www.worldometers.info/coronavirus/.

Mohammad Subhi Jamiluddin, Mohd Hafiz Mohd* \& Noor Atinah Ahmad

School of Mathematical Sciences

Universiti Sains Malaysia

11800 USM Penang, Pulau Pinang

Malaysia

Kamarul Imran Musa

School of Medical Sciences, Health Campus

Universiti Sains Malaysia

16150 Kubang Kerian, Kelantan Darul Naim

Malaysia

*Corresponding author; email: mohdhafizmohd@usm.my

Received: 30 January 2021

Accepted: 24 June 2021 